International Journal of Civil Engineering and Technology (IJCIET)

Volume 9, Issue 9, September 2018, pp. 1093-1103, Article ID: IJCIET_09_09_105

Available online at http://www.iaeme.com/ijciet/issues.asp?JType=IJCIET \&VType=9\&IType=9

ISSN Print: 0976-6308 and ISSN Online: 0976-6316

(C) IAEME Publication

Scopus Indexed

\title{
AUTOREGRESSION VECTOR PREDICTION ON BANKING STOCK RETURN USING CAPM MODEL APPROACH AND MULTI-FACTOR APT
}

\author{
Suroso Suroso, Rusiadi, Rahima Br. Purba, A. P. U. Siahaan, Ayu Kurnia Sari, Ade \\ Novalina, Annisa Ilmi Faried Lubis \\ Universitas Pembangunan Panca Budi, Medan, Indonesia
}

\begin{abstract}
This study aims to predict banking stock returns in Indonesia. The problem under study is the difficulty of determining banking stock returns. This study uses the VAR approach by comparing CAPM and APT. The results show the CAPM (Capital Asset Pricing Model) method through RF (Return Risk-Free Assets) is more accurate in predicting stock returns than the APT (Arbitrage Pricing Theory) method. In the medium term, the CAPM (Capital Asset Pricing Model) method through RF (Return Risk-Free Assets) is more accurate in predicting stock returns than the APT (Arbitrage Pricing Theory) method. In the long run, the CAPM (Capital Asset Pricing Model) method is also more accurate in predicting stock returns than the APT (Arbitrage Pricing Theory) method. Model specifications formed using the Roots of Characteristic Polynomial and Inverse Roots of AR Characteristic Polynomial obtained stable results; it can be shown that all roots units are in the Inverse Roots of AR Characteristic Polynomial circle.
\end{abstract}

Keywords: CAPM, APT, VAR Approach.

Cite this Article: Suroso Suroso, Rusiadi, Rahima Br. Purba, A. P. U. Siahaan, Ayu Kurnia Sari, Ade Novalina, Annisa Ilmi Faried Lubis, Autoregression Vector Prediction on Banking Stock Return Using CAPM Model Approach and Multi-Factor APT, International Journal of Civil Engineering and Technology, 9(9), 2018, pp. 10931103.

http://www.iaeme.com/IJCIET/issues.asp?JType=IJCIET\&VType=9\&IType=9

\section{INTRODUCTION}

In predicting the required or expected return on assets, two models are often used by investors, the Capital Assets Pricing Model (CAPM) and Arbitrage Pricing Theory (APT) [1]-[3]. Sharp and Lintner introduced Capital Assets Pricing Model (CAPM) which is a model for determining the price of an asset in equilibrium conditions [4]. In equilibrium, the level of profit required by investors for a stock will be affected by the stock [5]-[8] In this case, the 
calculated risk is the systematic risk represented by beta, because non-systematic risks can be eliminated by diversification. However, in the CAPM model, there are empirical weaknesses that occur that encourage financial management experts to look for alternative models that explain the relationship of income with stock risk [9]-[11] Stephen A. Ross in 1976 formulated a theory called Arbitrage Pricing Theory (APT) [12]. Although this model cannot completely solve the deficiencies that occur in the CAPM model, it is this model that was first developed to minimize the shortcomings that occur in the CAPM model and have the opportunity to replace the model. Both models can predict the expected return of investors but differ in the variables used. The following is information and an overview of the CAPM variable, one of which is risk-free assets. Risk-free assets in Indonesia are Bank Indonesia Certificates.

Table 1 Risk-free Asset Return $\left(\mathrm{R}_{\mathrm{f}}\right)$

\begin{tabular}{|c|c|c|c|c|c|}
\hline Period & $\mathbf{2 0 1 1}$ & $\mathbf{2 0 1 2}$ & $\mathbf{2 0 1 3}$ & $\mathbf{2 0 1 4}$ & $\mathbf{2 0 1 5}$ \\
\hline January & 0,06500 & 0,06000 & 0,05750 & 0,07500 & 0,07750 \\
\hline February & 0,06750 & 0,05750 & 0,05750 & 0,07500 & 0,07500 \\
\hline March & 0,06750 & 0,05750 & 0,05750 & 0,07500 & 0,07500 \\
\hline April & 0,06750 & 0,05750 & 0,05750 & 0.07500 & 0,07500 \\
\hline May & 0,06750 & 0,05750 & 0,05750 & 0,07500 & 0,07500 \\
\hline June & 0,06750 & 0,05750 & 0,06000 & 0,07500 & 0,07500 \\
\hline July & 0,06750 & 0,05750 & 0,06500 & 0,07500 & 0,07500 \\
\hline Agustu & 0,06750 & 0,05750 & 0,06500 & 0,07500 & 0,07500 \\
\hline September & 0,06750 & 0,05750 & 0,07000 & 0,07500 & 0,07500 \\
\hline October & 0,06500 & 0,05750 & 0,07250 & 0,07500 & 0,07500 \\
\hline November & 0,06000 & 0,05750 & 0,07250 & 0,07500 & 0,07500 \\
\hline Desember & 0,06000 & 0,05750 & 0,07500 & 0,07750 & 0,07500 \\
\hline$R_{f}$ & \multicolumn{5}{|l}{} \\
\hline
\end{tabular}

Source: www.bi.go.id, data processed, 2017

Figure 1 describes the monthly SBI interest rate is used to calculate risk-free asset returns. From the table above, the return calculation of the average risk-free asset (Rf) that the investor will receive is 0.06758 or $6.758 \%$ per month which includes a minimum interest rate of 0.05750 or $5.75 \%$ and a maximum interest rate of 0.07750 or $7.75 \%$. Many asset pricing models, the final result to be achieved is the certainty of the stock returns that have been predicted previously. According to C. A. Shook, the return is an investment profit, either through interest or dividends [13]. This stock return uses fluctuations from the closing stock price at the end of the month (monthly closing price) on some public companies.

Table 2 Stock returns $\left(\mathrm{R}_{\mathrm{i}}\right)$

\begin{tabular}{|l|l|l|l|}
\hline No. & \multicolumn{1}{|c|}{ Company } & \multicolumn{1}{c|}{ Code } & \multicolumn{1}{c|}{$\mathbf{E}\left(\mathbf{R}_{\mathbf{i}}\right)$} \\
\hline 1 & Bank Negara Indonesia Tbk. & BBNI & 0,01281 \\
\hline 2 & Bank Republik Indonesia Tbk. & BBRI & 0,02052 \\
\hline 3 & Bank Tabungan Negara Tbk. & BBTN & 0,00726 \\
\hline 4 & Bank Mandiri Tbk. & BMRI & 0,01254 \\
\hline \multicolumn{2}{|l}{ Average } & 0,01328 \\
\hline
\end{tabular}

Source: www.yahoofinance.com, data processed (2017)

Figure 2 explains that all stocks are showing positive $\mathrm{E}(\mathrm{Ri})$ values. A positive $\mathrm{E}$ ( $\mathrm{Ri}$ ) value indicates an increase in the share price that is greater than the decrease so that it will benefit 
investors and vice versa. The highest value of stock return is shown by BBNI (Bank Negara Indonesia Tbk.) Of 0.012815 and the lowest value of stock return at BBTN (Bank Tabungan Negara Tbk.) Of 0.00726. The average value of stock returns on the four stocks is 0.01328 . Beta $(\beta)$ shares, is a measure of market risk that affects the price of a stock. Beta measures the extent to which stock prices go up and down as market prices rise and fall. The beta value of the stock is obtained from the covariance results between the return of securities " $i$ " with the market return divided by the market return variant.

Table 3 Systematic Risk (Beta)

\begin{tabular}{|l|l|l|l|l|l|l|l|}
\hline No. & Code & 2011 & 2012 & 2013 & 2014 & 2015 & $\begin{array}{l}\text { Rata- } \\
\text { Rata }\end{array}$ \\
\hline 1 & BBNI & 2,0841 & 0,9116 & 0,9281 & 0,9204 & 1,4486 & 1,62172 \\
\hline 2 & BBRI & 1,9550 & 2,0079 & 1,8775 & 1,6736 & 1,6736 & 1,78203 \\
\hline 3 & BBTN & 1,5572 & 3,4324 & 0,9415 & 1,1711 & 2,2211 & 1,54127 \\
\hline 4 & BMRI & 1,6804 & 1,6035 & 1,8700 & 1,1441 & 1,7755 & 1,64876 \\
\hline \multicolumn{7}{|l|}{ Overall Beta } \\
\hline
\end{tabular}

Sumber: www.yahoofinance.com, data processed (2017)

Figure 3 explains that all stocks have the positive beta, it indicates that the increase in market return will increase the return on these stocks. The highest beta of the 4 shares is BBRI of 1.78203 . The overall beta average is 1.64846 . The following is information and an overview of APT variables. The rupiah exchange rate against the US dollar has decreased. This decline was due to the decline in fixed investment and public consumption. It has an impact on the sluggish opening of employment and affects the weakening of the exchange rate because the demand for the rupiah also declined while the exchange rate itself is one indicator to see whether a country's economic fundamentals are stable or not. According to previous research, the exchange rate is significant in predicting expected returns [14]. The following is a table of developments in the rates of exchange rates in Indonesia in 2011 to 2015 [15].

Table 4 Exchange Rate (IDR / USD)

\begin{tabular}{|c|c|c|c|}
\hline \multirow{2}{*}{ Year } & \multirow{2}{*}{ Rupiah } & \multicolumn{2}{|c|}{ Depreciation Development } \\
\cline { 3 - 4 } & & $\mathrm{Rp}$ & $\%$ \\
\hline 2011 & 9.068 & - & - \\
\hline 2012 & 9.670 & 602 & $7 \%$ \\
\hline 2013 & 12.189 & 2.519 & $26 \%$ \\
\hline 2014 & 12.440 & 251 & $2 \%$ \\
\hline 2015 & 13.795 & 1.355 & $11 \%$ \\
\hline
\end{tabular}

Source: www.bi.go.id, 2017

Figure 4 describes the unstable movement of the rupiah against the US dollar. In 2011 the rupiah exchange rate against the dollar was Rp. 9,068 per 1 US \$ and in 2015 reached Rp. 13,795 per 1 US \$. It is inseparable from Indonesia's exchange rate system which still uses a floating system. Each year the exchange rate of the rupiah against the US dollar continues to decline, especially in September 2015, the exchange rate of the rupiah against the US dollar penetrated Rp. 14,657 per 1 US \$. The decline in the rupiah exchange rate could have a negative impact on the global financial markets that experienced a crisis that affected macroeconomic variables such as inflation and the level of SBI. The inflation and SBI are significant in predicting expected returns. The following is data on the development of inflation rates from 2011 to 2015. The money supply in Indonesia from 2011 is Rp. 722,991 billion up to 2015, which is Rp. 1,055,440 billion continues to increase. It means that with the increase in the money supply, economic growth in Indonesia will increase. The money supply has a positive effect on economic growth. If there is an excess amount of money in circulation, Bank 
Indonesia will take a policy (reduce) the interest rate so that this condition encourages investors to make investments [16]-[19].

\section{THEORIES}

\subsection{Capital Asset Pricing Model (CAPM)}

In 1952, Harry Markowitz laid the foundation for modern portfolio management [20]. Then the first form of the CAPM standard was developed separately by Sharpe and Lintner. Capital Asset Pricing Model (CAPM) is a concentration of modern financial economics. This model provides a precise prediction of the relationship that should be observed between asset risk and estimated returns. Whereas according to CAPM model is a balanced model that describes the relationship of risk and return more simply because it uses only one variable (also called a beta variable) to describe risk [21].

In summary, the important CAPM assumptions are as follows:

1. There are no trading fees, no taxes and securities can be broken down to the smallest unit.

2. All participants are perfect competitors.

3. All investors have the same investment end.

4. Investors make investment decisions based on portfolio expected profits and profit standard deviations.

5. All investors have general expectations.

The formulation of the CAPM formula is as follows:

$$
R i=R f+\beta i(R m-R f)
$$

Where:

$$
\begin{array}{ll}
\mathrm{R}_{\mathrm{i}}= & \text { stock return } \mathrm{i} \\
\mathrm{R}_{\mathrm{f}}= & \text { risk free investment return } \\
\beta_{\mathrm{i}}= & \text { beta stock } \mathrm{i} \text { (indicator of systematic risk) } \\
\mathrm{R}_{\mathrm{m}}= & \text { return market }
\end{array}
$$

In CAPM, there is a relationship between risk and the level of return on investment in financial assets expressed by market lines, which consist of two types, such as:

- Security Market Line (SML)

The relationship between the security risk and the expected return on the SML line which is described in the beta and expected return space. The SML equation connects the expected return with the beta as follows:

$$
E(R i)=R f+\beta i(R m-R f)
$$

The market equilibrium situation of Security Market Line (SML) showed the tradeoff between risk and expected return for individual securities as a graphical representation of the CAPM model while the Capital Market Line (CML) is used to describe the tradeoff between risk and expected return for efficient portfolios, but not individual securities. For portfolios, additional expectation returns occur due to additional risk from the portfolio concerned. Individual securities for additional expectation returns are due to additional risk of individual securities measured by beta. 
- Capital Market Line (CML)

Capital Market Line (CML) is a line that describes a relationship between expected return and total risk in an efficient portfolio in a balanced market condition. Some things are needed to be considered for CML.

\subsection{Arbitrage Pricing Theory (APT)}

Arbitrage Pricing Theory (APT) is a theory developed by Stephen A. Ross in 1976 [12], where Ross stated that various factors could influence the price of an asset. Where the CAPM price is only influenced by one factor, namely the market portfolio (Rm). APT as an alternative model to answer the problem of a relationship between income and risk of shares $(\beta)$. Arbitrage Pricing Theory (APT) is useful for predicting the price of a stock in the future. In the APT return, the securities model is not only influenced by market portfolios because of the assumption that several other risk sources can influence the expected return from security. Arbitrage Pricing Theory (APT) primarily uses the idea that two investment opportunities that have identical characteristics cannot be sold at different prices (price one price) [22]. The concept used is one price law (the law of one price). If the same characteristic assets are sold at different prices, there will be an opportunity to arbitrage by buying low-priced assets and at the same time selling them at a high price so that they earn the profit without risk. Furthermore, this theory assumes that the level of profit can be influenced by various factors in the economy and industry. The correlation between the two securities levels of profit occurs because these securities are affected by the same factors.

There are 3 (three) assumptions underlying the Arbitrage Pricing Theory (APT) such as:

- Capital Market in perfect competition market conditions.

- Investors always prefer more than less wealth with certainty.

- The result of the stochastic process means that asset income can be considered as a factor $\mathrm{K}$ model.

The formula of APT is:

$R i=\alpha i+\beta i R m+e i$

Where:

$\mathrm{R}_{\mathrm{i}} \quad=$ return stock $\mathrm{i}$

$\alpha_{\mathrm{i}} \quad=$ alpha stock $\mathrm{i}$

$\beta_{\mathrm{i}} \quad=$ beta stock $\mathrm{i}$

$\mathrm{R}_{\mathrm{m}} \quad=$ market return

$\mathrm{e}_{\mathrm{i}} \quad=$ random error

The APT two-factor model formula is:

$R i=\alpha i+\beta i 1 F 1+\beta i 2 F 2+\ldots+\beta i n F n+e i$

Where:

$\mathrm{R}_{\mathrm{i}} \quad=\quad$ rate of return securities $\mathrm{i}$;

$\alpha_{i}=$ rate of return for securities $i$ if systematic risk is zero

$\mathrm{B}_{1,2, \ldots \mathrm{n}}=$ sensitivity of securities $\mathrm{i}$ to factors is considered

$\mathrm{F}_{1,2, . \mathrm{n}}=$ surprise for a factor (actual value-expected value)

$\mathrm{e}_{\mathrm{i}} \quad=$ term random error 


\section{METHODOLOGY}

This test is conducted to find out whether there is a simultaneous (interrelated) relationship between variables, as an exogenous variable and an endogenous variable by entering a time element (lag). This model can make predictive patterns of financial market integration in the short, medium and long-term from the simultaneity effect between variables.

VAR testing with the formula:

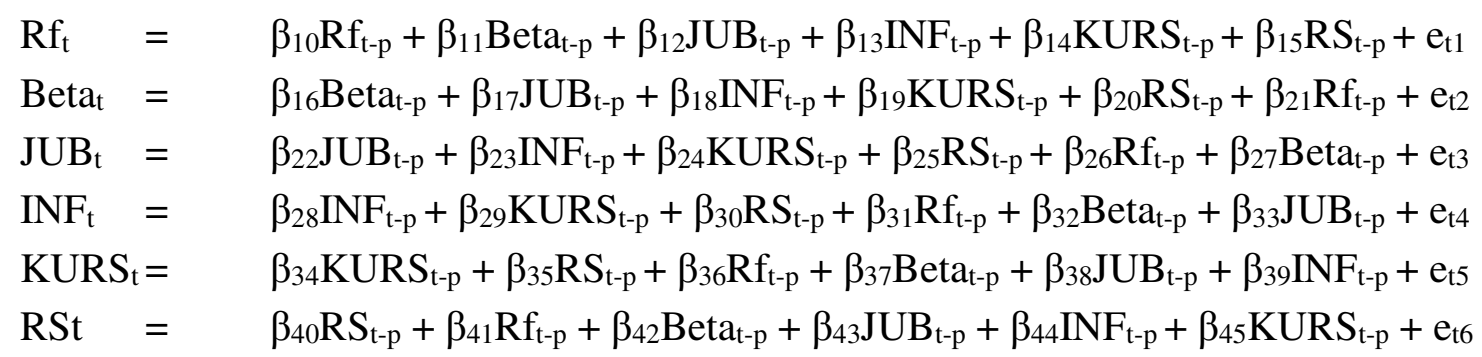

Where:

$\begin{array}{lll}\mathrm{Rf} & = & \text { risk free asset return } \\ \mathrm{Beta}= & \text { beta } \\ \mathrm{INF}= & \text { inflation }(\%) \\ \mathrm{KURS}= & \text { rupiah exchange rate against USD } \\ \mathrm{JUB}= & \text { amount of Money in circulation }(\%) \\ \mathrm{RS}= & \text { stock return } \\ \text { et } & = & \text { random disturbance } \\ \mathrm{p} & = & \text { lag length }\end{array}$

\section{RESULT AND DISCUSSION}

Variance decomposition aims to measure the estimated error variance of a variable, namely how big the difference before and aftershocks, whether derived from the variables themselves or other variables.

\subsection{Variance Decomposition BETA}

Based on the results of the research, it is obtained that BETA results in the short term (period 1), the estimated variance error is $100 \%$ which is explained by BETA itself, while the other variables are INF, JUB, KURS, RF, RS does not respond at all, where the response of these variables only appeared in the second period.

Table 5. Variance Decomposition BETA

\begin{tabular}{|c|c|c|c|c|c|c|c|}
\hline \multicolumn{7}{|c|}{ Variance Decomposition of BETA: } \\
\hline Period & S.E. & BETA & INF & LOGJUB & LOGKURS & RF & RS \\
\hline \hline 1 & 0.557148 & 100.0000 & 0.000000 & 0.000000 & 0.000000 & 0.000000 & 0.000000 \\
\hline 20 & 0.709900 & 79.72597 & 4.563846 & 2.877304 & 4.502216 & 7.762166 & 0.568499 \\
\hline 60 & 0.709913 & 79.72340 & 4.564179 & 2.879285 & 4.502363 & 7.762271 & 0.568507 \\
\hline
\end{tabular}

In the medium and long-term (period 20-60) the estimated variance error is $79.72 \%$ which is explained by BETA itself. Other variables that most influence BETA as policy variables other than BETA itself are RF at $7.76 \%$, then INF at $4.56 \%$, while the smallest affects KURS at $4.50 \%$, JUB at $2.87 \%$ and RS 0.57 does not affect BETA in the short term. 


\subsection{Variance Decomposition INF}

Based on the results of the study shown in Table 4.18, the result is that INF in the short term (period 1), estimates the variance error is $89.82 \%$ which is explained by the INF itself. Another variable that most influences the INF as a policy variable is in addition to the INF itself is BETA of $10.18 \%$, while other variables namely JUB, KURS, RF, and RS do not affect the INF in the short term.

Table 6 Variance Decomposition INF

\begin{tabular}{|c|c|c|c|c|c|c|c|}
\hline \multicolumn{8}{|c|}{ Variance Decomposition of INF: } \\
\hline Period & S.E. & BETA & INF & LOGJUB & LOGKURS & RF & RS \\
\hline & & & & & & & \\
\hline 1 & 1.588035 & 10.17909 & 89.82091 & 0.000000 & 0.000000 & 0.000000 & 0.000000 \\
\hline 2 & 2.087227 & 10.59479 & 85.13598 & 0.484413 & 0.051885 & 2.791343 & 0.941583 \\
\hline 3 & 2.352786 & 8.489943 & 82.22246 & 0.646942 & 0.370705 & 7.490641 & 0.779311 \\
\hline 4 & 2.533619 & 7.350987 & 77.51916 & 0.684708 & 0.981977 & 12.77586 & 0.687309 \\
\hline 5 & 2.657061 & 6.841567 & 73.26287 & 0.622656 & 1.633621 & 17.01082 & 0.628472 \\
\hline 20 & 3.100048 & 7.135698 & 55.85657 & 11.19259 & 3.205194 & 21.98835 & 0.621604 \\
\hline 21 & 3.104525 & 7.119176 & 55.72355 & 11.38988 & 3.206154 & 21.94086 & 0.620379 \\
\hline 22 & 3.107865 & 7.106277 & 55.62371 & 11.53433 & 3.208433 & 21.90785 & 0.619407 \\
\hline 23 & 3.110319 & 7.096461 & 55.54986 & 11.63856 & 3.211235 & 21.88523 & 0.618657 \\
\hline 24 & 3.112096 & 7.089151 & 55.49599 & 11.71275 & 3.214061 & 21.86995 & 0.618092 \\
\hline 60 & 3.116190 & 7.071468 & 55.36920 & 11.87576 & 3.225822 & 21.84107 & 0.616685 \\
\hline
\end{tabular}

In the long run (period 60) an estimated variance error of $55.36 \%$ is explained by the INF itself. The other variable that most influences INF as a policy variable other than INF itself is RF of $21.84 \%$, then JUB is $11.87 \%$, while the smallest affects BETA of $7.07 \%$, KURS of $3.22 \%$ and $\mathrm{RS}$ amounting to $0.61 \%$.

\subsection{Variance Decomposition JUB}

Based on the results of the study as shown in the previous table, the results obtained that JUB in the short term (period 1), estimates the variance error of $92.20 \%$ described by JUB itself. Another variable that most influences JUB as a policy variable is JUB itself is INF of $7.52 \%$ then BETA of $0.26 \%$, while other variables, namely KURS, RF, and RS do not affect JUB in the short term.

Table 7 Variance Decomposition JUB

\begin{tabular}{|c|c|c|c|c|c|c|c|}
\hline \multicolumn{7}{|c|}{ Variance Decomposition of LOGJUB: } \\
\hline Period & S.E. & BETA & INF & LOGJUB & LOGKURS & RF & RS \\
\hline 1 & 0.021414 & 0.263501 & 7.529855 & 92.20664 & 0.000000 & 0.000000 & 0.000000 \\
\hline 2 & 0.028282 & 0.213738 & 5.833842 & 93.12918 & 0.000256 & 0.822705 & 0.000277 \\
\hline 3 & 0.033061 & 0.901923 & 4.521662 & 93.00375 & 0.000463 & 1.524831 & 0.047374 \\
\hline 4 & 0.036596 & 1.284854 & 3.690202 & 92.82160 & 0.001198 & 2.119393 & 0.082758 \\
\hline 5 & 0.039485 & 1.814618 & 3.254308 & 92.42581 & 0.001120 & 2.373295 & 0.130845 \\
\hline 20 & 0.051655 & 2.787432 & 4.497735 & 90.07688 & 0.326846 & 2.060587 & 0.250523 \\
\hline 21 & 0.051711 & 2.782722 & 4.504852 & 90.04755 & 0.339639 & 2.075006 & 0.250228 \\
\hline 22 & 0.051750 & 2.779213 & 4.509404 & 90.02547 & 0.349562 & 2.086352 & 0.249999 \\
\hline 23 & 0.051778 & 2.776653 & 4.512256 & 90.00910 & 0.357112 & 2.095055 & 0.249825 \\
\hline 24 & 0.051797 & 2.774819 & 4.514007 & 89.99714 & 0.362757 & 2.101582 & 0.249697 \\
\hline 60 & 0.051836 & 2.770799 & 4.516370 & 89.96890 & 0.376852 & 2.117679 & 0.249396 \\
\hline
\end{tabular}


In the long run (period 60) the estimated variance error is $89.97 \%$ which is explained by JUB itself. Another variable that most influences JUB as a policy variable other than JUB itself is the INF of $4.52 \%$, BETA of $2.77 \%$, RF of $2.11 \%$, then the smallest affecting JUB is KURS of $0.38 \%$, and RS is 0.25 .

\subsection{Variance Decomposition KURS}

Based on the results of the study shown in Table 4.18, the results of the KURS are in the short term (period 1), the estimated variance error is $36.08 \%$ which is explained by KURS itself. Other variables that most influence KURS as a policy variable are beside KURS itself is JUB of $50.79 \%$ then BETA of $6.78 \%$, INF of $6.34 \%$, and JUB while other variables namely RF and RS do not affect KURS in short-term.

Table 8 Variance Decomposition KURS

\begin{tabular}{|c|c|c|c|c|c|c|c|}
\hline \multicolumn{7}{|c|}{ Variance Decomposition of LOGKURS: } \\
\hline Period & S.E. & BETA & INF & LOGJUB & LOGKURS & RF & RS \\
\hline & & & & & & & \\
\hline 1 & 0.027889 & 6.782178 & 6.343871 & 50.78955 & 36.08440 & 0.000000 & 0.000000 \\
\hline 2 & 0.036810 & 4.954082 & 6.551200 & 60.60855 & 27.81902 & 0.007934 & 0.059220 \\
\hline 3 & 0.043101 & 4.797644 & 6.338882 & 67.21113 & 21.52013 & 0.031925 & 0.100287 \\
\hline 4 & 0.047747 & 4.409864 & 6.277415 & 71.41354 & 17.72636 & 0.055283 & 0.117540 \\
\hline 5 & 0.051431 & 4.255834 & 6.226038 & 73.99635 & 15.28163 & 0.102458 & 0.137690 \\
\hline 20 & 0.063702 & 3.533056 & 6.529048 & 78.44357 & 10.53135 & 0.790424 & 0.172551 \\
\hline 21 & 0.063736 & 3.529691 & 6.529488 & 78.44023 & 10.52806 & 0.800071 & 0.172462 \\
\hline 22 & 0.063760 & 3.527302 & 6.529631 & 78.43733 & 10.52613 & 0.807215 & 0.172394 \\
\hline 23 & 0.063776 & 3.525626 & 6.529616 & 78.43493 & 10.52505 & 0.812428 & 0.172342 \\
\hline 24 & 0.063787 & 3.524463 & 6.529526 & 78.43304 & 10.52449 & 0.816182 & 0.172304 \\
\hline 60 & 0.063810 & 3.522062 & 6.528900 & 78.42783 & 10.52429 & 0.824708 & 0.172215 \\
\hline
\end{tabular}

In the medium and long-term (period 20 and period 60) the estimated variance error is $10.53 \%$ which is explained by KURS itself. Other variables that most influence KURS as a policy variable besides KURS itself are JUB of $78.42 \%$, INF of $6.53 \%$, BETA of $3.52 \%$, then the smallest affecting RF of $0.82 \%$ and RS of $0.17 \%$.

\subsection{Variance Decomposition RF}

Based on the results of the research shown in Table 4.48, the results of RF in the short term obtained (period 1), estimated the RF itself explains the variance error of $75.88 \%$. The most significant variable affecting RF as a policy variable is BETA of $13.74 \%$ then KURS $9.89 \%$, INF of $0.45 \%$, JUB $0.038 \%$ and whereas RS does not affect RF in the short term.

Table 9 Variance Decomposition RF

\begin{tabular}{|c|c|c|c|c|c|c|c|}
\hline \multicolumn{8}{|c|}{ Variance Decomposition of RF: } \\
\hline Period & S.E. & BETA & INF & LOGJUB & LOGKURS & RF & RS \\
\hline 1 & 0.365674 & 13.74189 & 0.454634 & 0.037666 & 9.886977 & 75.87884 & 0.000000 \\
\hline 2 & 0.483449 & 16.86582 & 2.010697 & 1.576530 & 11.18031 & 67.27686 & 1.089788 \\
\hline 3 & 0.543444 & 16.94997 & 3.926126 & 4.562870 & 11.55434 & 61.85950 & 1.147203 \\
\hline 4 & 0.585991 & 17.28943 & 5.647105 & 8.729678 & 11.10885 & 55.99879 & 1.226147 \\
\hline 5 & 0.617484 & 16.88623 & 7.115928 & 13.06578 & 10.46128 & 51.24632 & 1.224456 \\
\hline 20 & 0.737400 & 13.39476 & 9.889800 & 30.86673 & 7.862434 & 36.96935 & 1.016927 \\
\hline 21 & 0.737616 & 13.38692 & 9.887062 & 30.88719 & 7.864897 & 36.95759 & 1.016342 \\
\hline 22 & 0.737754 & 13.38191 & 9.885151 & 30.89987 & 7.866778 & 36.95032 & 1.015966 \\
\hline 23 & 0.737842 & 13.37875 & 9.883848 & 30.90764 & 7.868157 & 36.94588 & 1.015728 \\
\hline 24 & 0.737896 & 13.37679 & 9.882980 & 30.91233 & 7.869135 & 36.94318 & 1.015579 \\
\hline 60 & 0.737980 & 13.37379 & 9.881452 & 30.91900 & 7.871101 & 36.93931 & 1.015349 \\
\hline
\end{tabular}


In the medium term (period 20) the estimated variance error is $36.97 \%$, which is explained by the RF itself. Another variable that most influences RF as a policy variable other than RF itself is JUB of $30.87 \%$, BETA of $13.38 \%$ and KURS of $7.87 \%$, then the smallest affecting JUB of $9.87 \%$ and RS of $0.15 \%$.

\subsection{Variance Decomposition RS}

Based on the results of the research shown in the previous table, the results show that the RS is in the short term (period 1), the estimated variance error of $40.78 \%$ is explained by the RS itself. The most significant variable affecting RS as a policy variable is RF of $35.80 \%$ then KURS $12.94 \%$, BETA of $6.51 \%$, INF of $3.94 \%$ and JUB of $0.03 \%$.

Table 10 Variance Decomposition RS

\begin{tabular}{|c|c|c|c|c|c|c|c|}
\hline \multicolumn{7}{|c|}{ Variance Decomposition of RS: } \\
\hline Period & S.E. & BETA & INF & LOGJUB & LOGKURS & RF & RS \\
\hline & & & & & & & \\
\hline 1 & 0.020113 & 6.507640 & 3.938380 & 0.025140 & 12.94665 & 35.80010 & 40.78209 \\
\hline 2 & 0.021879 & 6.245411 & 5.934162 & 0.535367 & 19.30876 & 33.29773 & 34.67857 \\
\hline 3 & 0.022796 & 7.660510 & 8.071163 & 0.721741 & 19.58874 & 31.47064 & 32.48720 \\
\hline 4 & 0.023165 & 7.536070 & 9.909027 & 1.003378 & 19.53721 & 30.52339 & 31.49093 \\
\hline 5 & 0.023410 & 7.578157 & 10.98581 & 1.174966 & 19.40440 & 29.98396 & 30.87270 \\
\hline 20 & 0.024477 & 7.353540 & 11.48739 & 5.443996 & 18.21811 & 29.22250 & 28.27446 \\
\hline 21 & 0.024493 & 7.346606 & 11.48550 & 5.546400 & 18.19677 & 29.18766 & 28.23707 \\
\hline 22 & 0.024506 & 7.340852 & 11.48373 & 5.624347 & 18.18100 & 29.16187 & 28.20820 \\
\hline 23 & 0.024515 & 7.336226 & 11.48212 & 5.682678 & 18.16956 & 29.14313 & 28.18628 \\
\hline 24 & 0.024522 & 7.332612 & 11.48071 & 5.725657 & 18.16141 & 29.12972 & 28.16989 \\
\hline 60 & 0.024540 & 7.322721 & 11.47542 & 5.829346 & 18.14396 & 29.10003 & 28.12852 \\
\hline
\end{tabular}

In the medium term (period 20) the estimated variance error is $28.27 \%$ which is explained by RS itself. Other variables that most influence RS as policy variables other than RS itself are RF of $29.22 \%$, KURS of $18.22 \%$, and INF of $11.47 \%$, then the smallest affects BETA of $7.35 \%$ and JUB of $5.44 \%$. In the long run (period 60) the estimated variance error is $28.12 \%$ which is explained by RS itself. Other variables that most influence RS as policy variables other than RS itself are RF of $29.10 \%$, KURS of $18.14 \%$, and INF of $11.48 \%$, then the smallest affects BETA of $7.32 \%$ and JUB of $5.83 \%$.

Table 11 Variance Decompotion Result

\begin{tabular}{|c|c|c|c|c|c|}
\hline Method & Variable & Short & Medium & Long & Return Saham \\
\hline \multirow{2}{*}{ CAPM } & BETA & 6,508 & 7,353 & 7,322 & - \\
\cline { 2 - 6 } & RF & 35,80 & 29,22 & 29,10 & \\
\hline \multirow{3}{*}{ APT } & INF & 3,938 & 11,49 & 11,46 & - \\
\cline { 2 - 6 } & JUB & 0,025 & 5,444 & 5,83 & - \\
\cline { 2 - 6 } & KURS & 12,94 & 18,22 & 18,14 & - \\
\hline
\end{tabular}

Based on the explanation of the results of variance decomposition it is known that in the short term the Capital Asset Pricing Model (CAPM) through RF (Return Risk-Free Assets) is more accurate in predicting stock returns than the APT (Arbitrage Pricing Theory) method. In the medium term, the CAPM (Capital Asset Pricing Model) method through RF (Return RiskFree Assets) is more accurate in predicting stock returns than the APT (Arbitrage Pricing Theory) method. In the long run, the CAPM (Capital Asset Pricing Model) method is also more accurate in predicting stock returns than the APT (Arbitrage Pricing Theory) method. 


\section{CONCLUSION}

Estimation results using Vector Autoregression (VAR), shows the results of the relationship between BETA, INF, JUB, EXCHANGE, RF and RS with lag 1. It can be concluded that by observing the $\mathrm{t}$-statistics of each coefficient, the reciprocal relationship between Beta, Inflation variables, Amount of Money Supply, Exchange Rate, Free Asset Return, and Stock Return are statistically significant. Other variables besides the variables that have the most significant contribution to BETA are KURS. The variables that have the most significant contribution to INF are RS. The variable that has the most significant contribution to JUB besides JUB itself is RF. Variables that have the most substantial contribution to KURS in addition to KURS itself are JUB. The variable that has the most significant contribution to RF is KURS. The variable that has the most significant contribution to RS is JUB. Based on the results of the Impulse response function, it is known that the stability of all variables is in the 20th or medium-term period, this implies that even though there are short-term variables that do not affect but in the medium and long-term; they will influence each other. The results of Variance Decomposition Analysis in the short term CAPM method (Capital Asset Pricing Model) through RF (Return Risk-Free Assets) are more accurate in predicting stock returns than the APT (Arbitrage Pricing Theory) method. In the medium term, the CAPM (Capital Asset Pricing Model) method through RF (Return Risk-Free Assets) is more accurate in predicting stock returns than the APT (Arbitrage Pricing Theory) method. In the long run, the CAPM (Capital Asset Pricing Model) method is also more accurate in predicting stock returns than the APT (Arbitrage Pricing Theory) method.

\section{REFERENCES}

[1] T. Yu, H. Liu, D. Wang, and G. Yang, "Applied Research on Capital Asset Pricing Model in Premium Rate Making of Engineering Earthquake Insurance," in 2011 International Conference on Information Management, Innovation Management and Industrial Engineering, 2011, pp. 82-86.

[2] W. Bao and M. Yang, "Study on liquidity premium based on three-moment capital asset pricing model," in 2013 10th International Conference on Service Systems and Service Management, 2013, pp. 440-444.

[3] D. Ruslan, Rusiadi, A. Novalina, and A. I. F. Lubis, "EARLY DETECTION OF THE FINANCIAL CRISIS OF DEVELOPING COUNTRIES," Int. J. Civ. Eng. Technol., vol. 9, no. 7, pp. 584-597, 2018.

[4] R. Bird, G. Menzies, P. Dixon, and M. Rimmer, "The economic costs of US stock mispricing," J. Policy Model., vol. 33, no. 4, pp. 552-567, Jul. 2011.

[5] M. J. Ledwith, "An agent based modeling framework to evaluate the Capital Asset Pricing Model," in 2009 Systems and Information Engineering Design Symposium, 2009, pp. 16.

[6] Rusiadi, Ramli, D. Ruslan, and R. Ginting, "MONETARY TRANSMISSION OF STATE EMERGING MARKETS LINE ASSET PRICES: INFLATION CONTROL LEADING INDICATORS," Int. J. Civ. Eng. Technol., vol. 9, no. 7, pp. 698-707, 2018.

[7] Rusiadi et al., "Simultaneous Response of Dividend Policy and Value of Indonesia Manufacturing Companies An Approach of Vector Autoregression," Int. J. Civ. Eng. Technol., vol. 9, no. 6, pp. 313-323, 2018.

[8] M. D. T. P. Nasution, Y. Rossanty, P. B. Sari, and A. P. U. Siahaan, "Online Shoppers Acceptance: an Exploratory Study," Int. J. Civ. Eng. Technol., vol. 9, no. 6, pp. 793-799, 2018. 
[9] P. Zhang and F. Chen, "The CAPM Applicability Study on Chinese Stock Markets," in 2009 International Workshop on Intelligent Systems and Applications, 2009, pp. 1-4.

[10] Y. Rossanty, S. Aryza, M. D. T. P. Nasution, and A. P. U. Siahaan, "Design Service of QFC And SPC Methods in the Process Performance Potential Gain and Customers Value in a Company," Int. J. Civ. Eng. Technol., vol. 9, no. 6, pp. 820-829, 2018.

[11] A. Sanusi et al., "GCG Simultaneity Effects, Profit Management And Value Of Indonesian Retail Companies,” Int. J. Civ. Eng. Technol., vol. 9, no. 7, pp. 1506-1518, 2018.

[12] S. A. Ross, "The arbitrage theory of capital asset pricing," J. Econ. Theory, vol. 13, no. 3, pp. 341-360, Dec. 1976.

[13] C. A. Shook and A. S. Bartosik, "Particle—wall stresses in vertical slurry flows," Powder Technol., vol. 81, no. 2, pp. 117-124, Nov. 1994.

[14] A. El-Masry and O. Abdel-Salam, "Exchange rate exposure: do size and foreign operations matter?," Manag. Financ., vol. 33, no. 9, pp. 741-765, Aug. 2007.

[15] R. E. Wimanda, "Threshold effects of exchange rate depreciation and money growth on inflation,” J. Econ. Stud., vol. 41, no. 2, pp. 196-215, Mar. 2014.

[16] E. G. Hutapea and R. A. Kasri, "Bank margin determination: a comparison between Islamic and conventional banks in Indonesia," Int. J. Islam. Middle East. Financ. Manag., vol. 3, no. 1, pp. 65-82, Apr. 2010.

[17] A. Ikhwan, M. Yetri, Y. Syahra, and J. Halim, "A Novelty of Data Mining for Promoting Education based on FP-Growth Algorithm," Int. J. Civ. Eng. Technol., vol. 9, no. 7, pp. 1660-1669, 2018.

[18] Supiyandi, M. I. Perangin-angin, A. H. Lubis, A. Ikhwan, Mesran, and A. P. U. Siahaan, "Association Rules Analysis on FP-Growth Method in Predicting Sales," Int. J. Recent Trends Eng. Res., vol. 3, no. 10, pp. 58-65, 2017.

[19] M. Dharma Tuah Putra Nasution, A. Putera Utama Siahaan, Y. Rossanty, and S. Aryza, "Entrepreneurship Intention Prediction using Decision Tree and Support Vector Machine," in Proceedings of the Joint Workshop KO2PI and The 1st International Conference on Advance \& Scientific Innovation, 2018.

[20] H. Markowitz, "PORTFOLIO SELECTION*," J. Finance, vol. 7, no. 1, pp. 77-91, Mar. 1952.

[21] S. Lee and A. Upneja, "Is Capital Asset Pricing Model (CAPM) the best way to estimate cost-of-equity for the lodging industry?," Int. J. Contemp. Hosp. Manag., vol. 20, no. 2, pp. 172-185, Mar. 2008.

[22] D. U. A. Galagedera, "A review of capital asset pricing models," Manag. Financ., vol. 33, no. 10, pp. 821-832, Sep. 2007. 